\title{
Application of three intragenic DNA polymorphisms for carrier detection in haemophilia B
}

\author{
J M CONNOR*, A F PETTIGREW†, C SHIACH + , I M HANN $\dagger$, G D O LOWE \\ AND C D FORBES† \\ From * the University Department of Medical Genetics, Duncan Guthhrie Institute of Medical Genetics, Glasgow; \\ and the Department of Haematology, University of Glasgow.
}

SUMMARY In the west of Scotland use of a single intragenic restriction fragment length polymorphism ( $F 9$ (VIII)/TaqI) allowed definitive genetic counselling for $45 \%$ of females at risk of being carriers for haemophilia B. Two further intragenic RFLPs, F9(VIII)/XmnI) and F9(XIII)/DdeI, have been applied to this population and by using all three polymorphisms the carrier status could be determined in $68 \%$ of females at risk. Linkage disequilibrium was apparent between these three RFLPs, and in the west of Scotland the single most clinically usefu polymorphism was $F 9$ (VIII)/TaqI followed by $F 9$ (XIII)/DdeI and then $F 9$ (VIII)/XmnI. Overall, prenatal diagnosis by DNA analysis could be offered to 31 of $37(84 \%)$ carriers (obligate and detected) in these families.

DNA analysis using intragenic or closely linked restriction fragment length polymorphisms (RFLPs) is rapidly gaining acceptance as a reliable and practical approach to carrier detection in both haemophilia $\mathrm{B}^{1-4}$ and haemophilia A. ${ }^{56} \mathrm{~A}$ single factor IX intragenic RFLP (F9(VIII)/TaqI) was informative for $42 \%$ of obligate carriers and permitted definitive counselling of 14 of $31(45 \%)$ females at risk who were tested in the west of Scotland. ${ }^{4}$ We wish to report our experience with the two other known factor IX RFLPs in these previously reported families and in one further family from the west of Scotland.

\section{Methods}

The methods for DNA extraction, digestion, and the identification of specific fragments have been described previously ${ }^{4}$ and only modifications are outlined below. Probe VIII is a $2.5 \mathrm{~kb}$ segment of the factor IX gene comprising $2.4 \mathrm{~kb}$ of introns and the 'd' exon. ${ }^{7}$ Fragment polymorphisms can be identified with this probe using the restriction enzymes $\operatorname{Taq}^{1}$ and $X m n I^{2}{ }^{2}$ Probe XIII identifies a fragment polymorphism using DdeI. ${ }^{2}$ In this latter RFLP the fragments differ in size by only $50 \mathrm{bp}$ and, in order to demonstrate this, electrophoresis was performed in $17 \mathrm{~cm} 1 \cdot 2 \%$ agarose gels after ethanol precipitation of the digests. Hybond $\mathrm{N}$ (Amersham) was used in

Received for publication 27 October 1985

Revised version accepted for publication 22 November 1985. place of nitrocellulose for Southern blotting in these experiments.

\section{Results}

Probe VIII identifies two bands in TaqI digested DNA from males and two or three bands in TaqI digested DNA from female subjects. The $5.3 \mathrm{~kb}$ band occurred in all subjects and the polymorphic fragments were $1.8 \mathrm{~kb}$ or $1.3 \mathrm{~kb}$. When DNA is digested with $X m n I$ and probed with VIII only a single band is apparent in males $(11.5 \mathrm{~kb}$ or $6.5 \mathrm{~kb})$, whereas females may be homozygous for either fragment or heterozygous $(11.5 \mathrm{~kb} / 6.5 \mathrm{~kb})$. Probe XIII similarly only identifies a single band in DdeI digested male DNA $(1.75 \mathrm{~kb}$ or $1.7 \mathrm{~kb})$ whereas females may be homozygous for either fragment or heterozygous.

Fig 1 illustrates these RFLPs and the frequency of each fragment for unrelated Scottish subjects is indicated in table 1. From the Hardy-Weinberg equilibrium the expected heterozygote frequencies for each RFLP are $F 9$ (VIII)/TaqI $46 \%, F 9$ (VIII)/ $X m n I \quad 43 \%$, and $F 9$ (XIII)/DdeI $35 \%$.

Ten families from the west of Scotland segregating for haemophilia B have been studied to date. The pedigrees of nine of these have already been described $^{4}$ and are presented with results of carrier detection and outcomes of recent pregnancies in figs 2 to 11 . In family 1756 (fig 2), III.9 underwent prenatal diagnosis after amniocentesis and a male fetus without haemophilia B was predicted by DNA analysis. Unfortunately, this pregnancy was also at a 


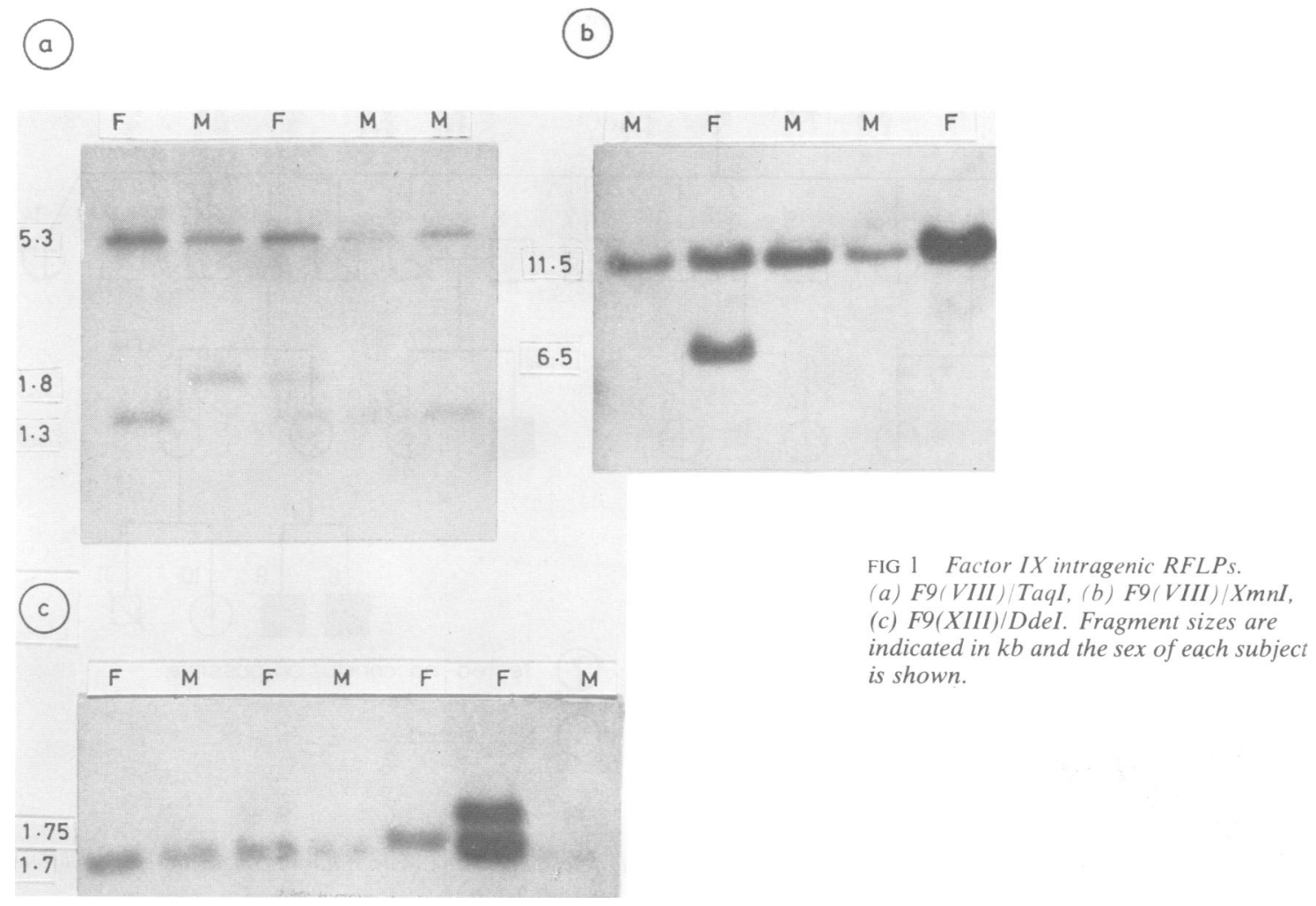

1 in 4 risk for cystic fibrosis as IV.10 is so affected. Amniotic fluid biochemistry and ultrasonography suggested a recurrence of cystic fibrosis which was confirmed at necropsy after termination of pregnancy. Family 5215 (fig 11) were referred for genetic counselling of the consultand II.4. The obligate carrier I.2 is informative for both F9(VIII)/TaqI and F9(VIII)/XmnI. Paternal absence prevents interpretation for the second of these polymorphisms, but the consultand II.4 is homozygous $1.3 \mathrm{~kb} / 1.3 \mathrm{~kb}$ for the

TABLI: 1 Fragment frequencies for factor IX intragenic RFLPs in Scottish suhjects.

\begin{tabular}{lcll}
\hline RFLP & $\begin{array}{l}\text { Polymorphic } \\
\text { fragments } \\
(\mathrm{kb})\end{array}$ & Frequency & $\begin{array}{l}\text { No of } \\
\text { unrelated } X \\
\text { chromosomes amalysed }\end{array}$ \\
\hline F9(VIII)/TaqI & 1.8 & 0.63 & 46 \\
& 1.3 & 0.37 & \\
F9(VIII)/X mnI & 11.5 & 0.68 & 60 \\
& 6.5 & 0.32 & \\
F9(XIII)/DdeI & 1.75 & 0.23 & 30 \\
& 1.7 & 0.77 & \\
\hline
\end{tabular}

first polymorphism and is thus not a carrier, as in this family haemophilia $B$ is linked to the $1.8 \mathrm{~kb}$ fragment.

Table 2 shows the RFLP results for the obligate carriers in these 10 families. Among the haemophilia B obligate carriers, $46 \%(13 / 28)$ were informative for F9(VIII)/TaqI, $30 \%(8 / 27)$ were informative for $F 9$ (VIII)/XmnI, and $44 \%(12 / 27)$ were informative for $F 9(X I I I) / D d e I$. Six of the 28 obligate carriers were not informative for any RFLP, 12 were informative for a single RFLP, nine for two, and one carrier was informative for all three RFLPs.

Thirty-one females at risk have been traced and tested. DNA analysis indicated that six females were carriers and that 15 were not; no conclusion was possible from DNA analysis for 10 females at risk (table 3, figs 2 to 11). Three females at risk who could not be counselled on the basis of DNA analysis had levels of factor IX coagulant activity well outside our normal range, as determined by the one stage clotting assay based on partial thromboplastin time (pedigree 4549, III.5: factor IX level $52 \%$; pedigree 4565, IV.2: level $42 \%$; and pedigree 4555 , IV.4: level $50 \%$ ). Although normal coagulant studies do not exclude 


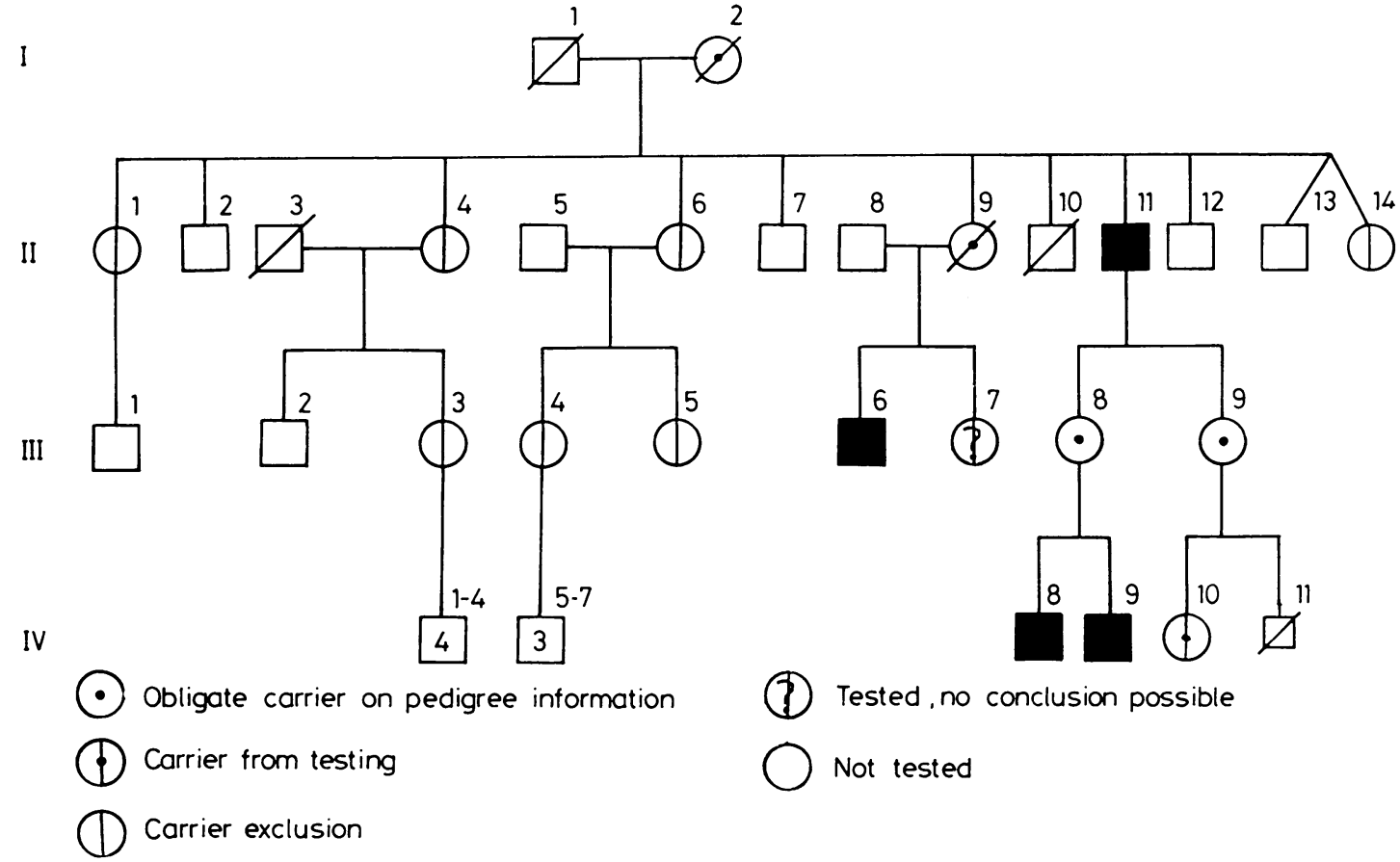

Hig 2 Pedigree 1756.

HIGS 2-10 Pedigrees of families with haemophilia B from the west of Scotland. The carrier status of female's in the'se pedigree's is indicated.

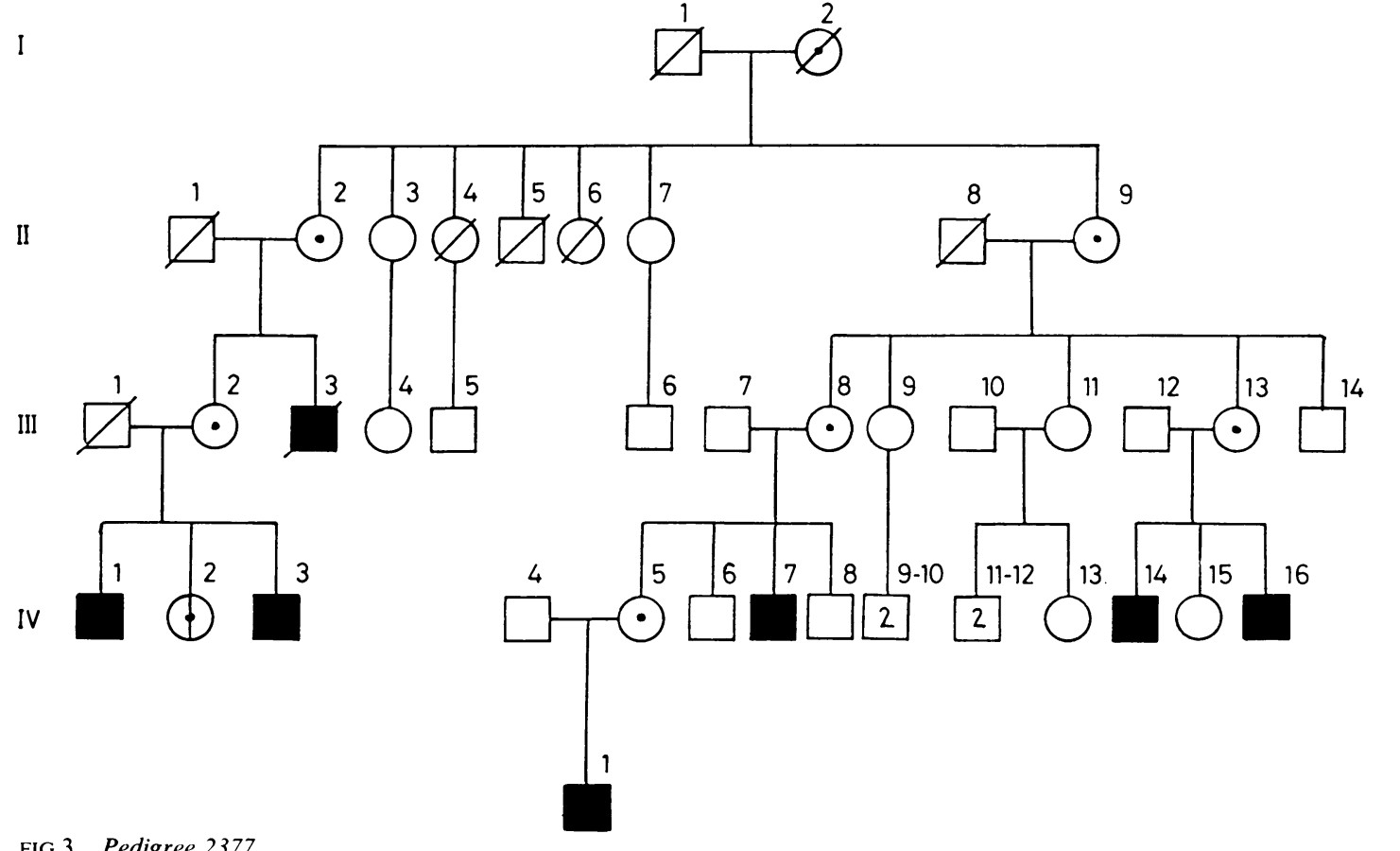

FIG 3 Pedigree 2377 
Application of three intragenic DNA polymorphisms for carrier detection in haemophilia B

I

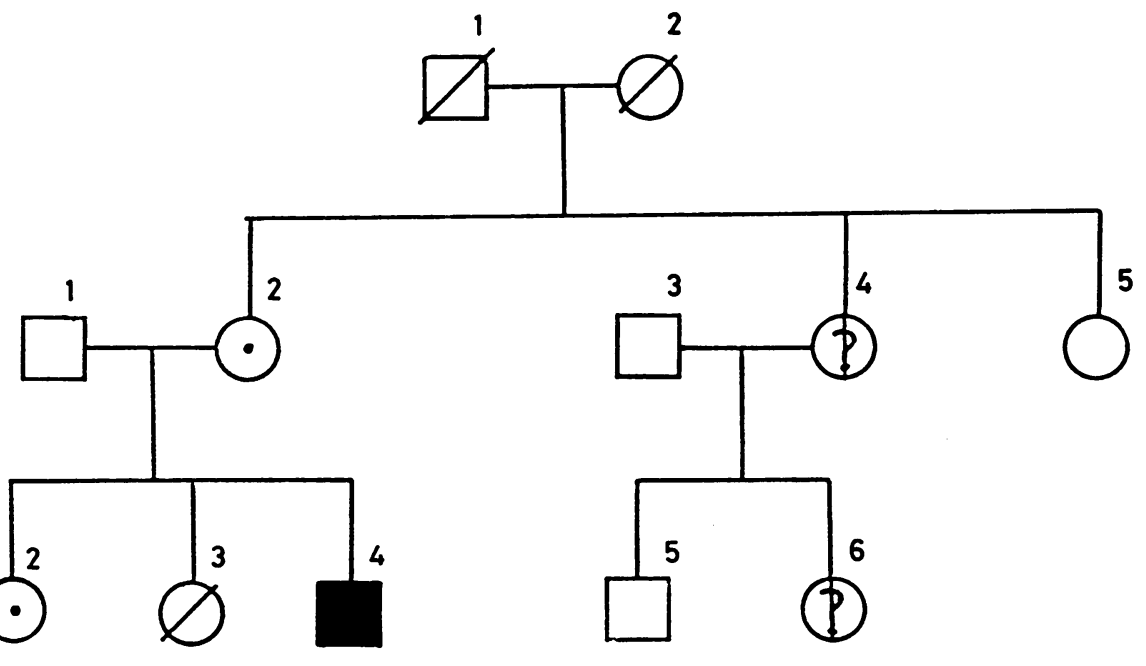

II

III

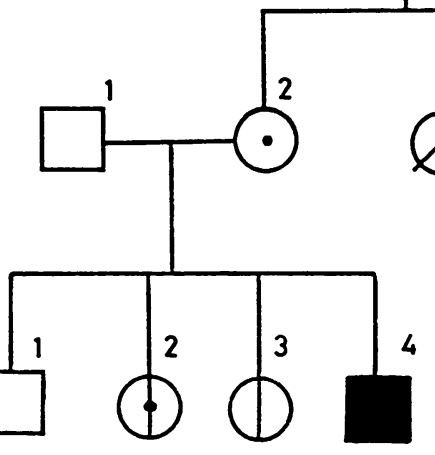

FIG 4 Pedigree 3569.

1

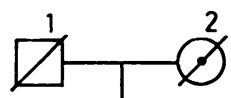

II
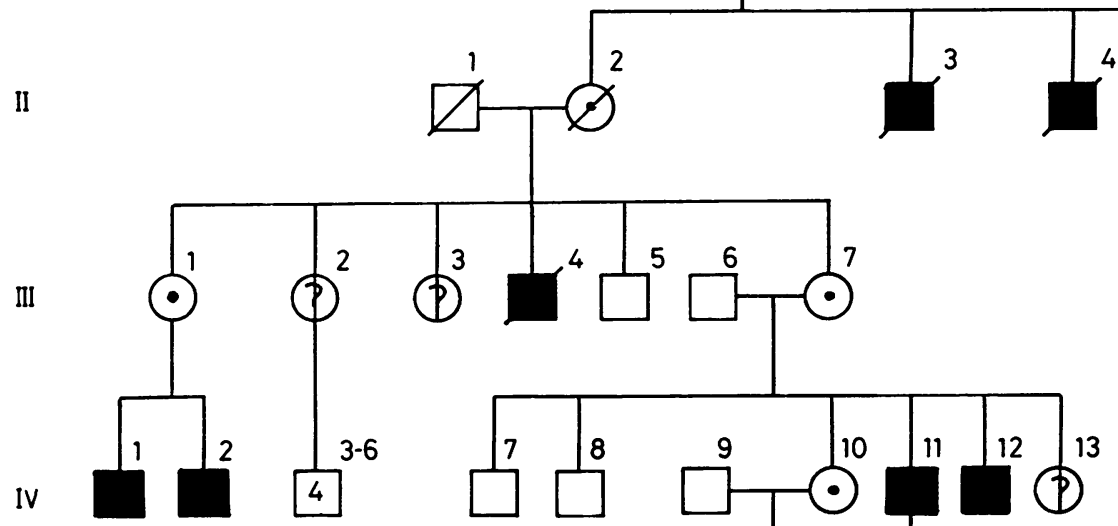

v

fIG 5 Pedigree 4542.
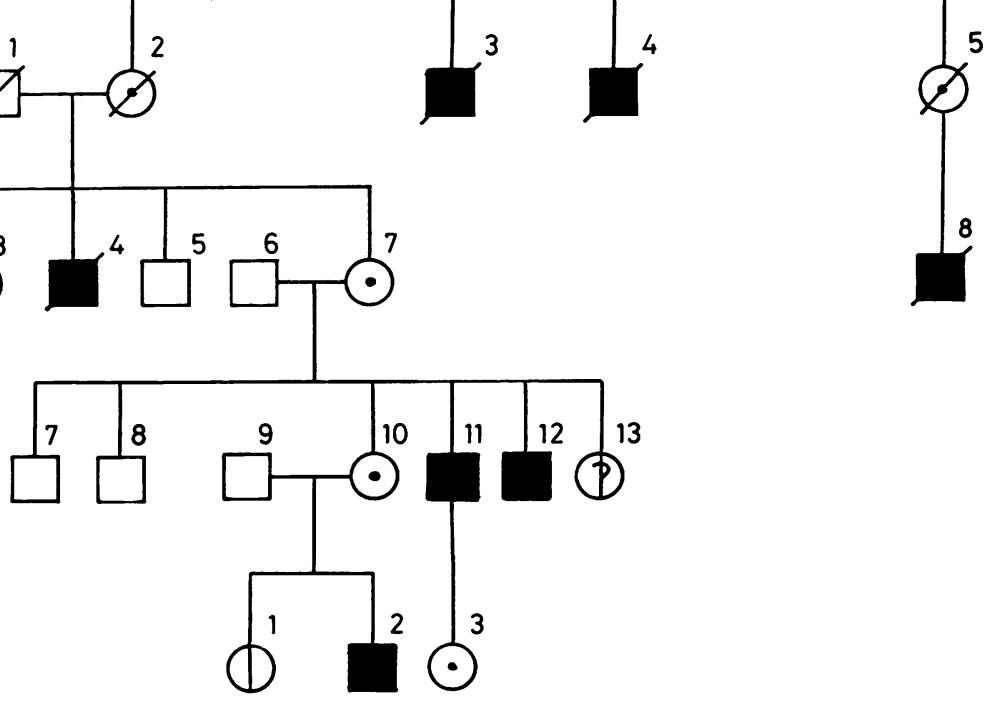
I

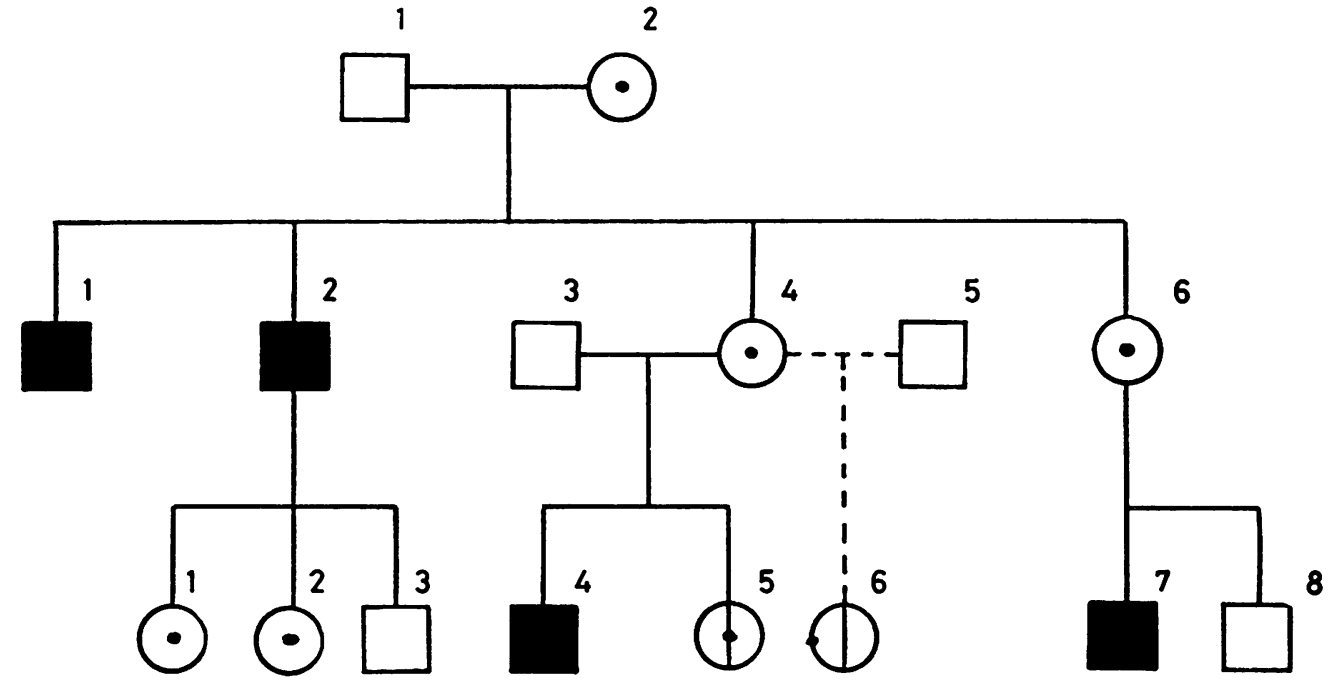

III

Pedigree 4549.

carrier status of haemophilia $B$, these abnormal results indicate a high probability that these three females are carriers. Thus, DNA analysis permitted definitive genetic counselling in $68 \%$ of females at risk and, if combined with the above coagulation results, $77 \%$ of females at risk could be counselled.

Of the 21 females whose carrier status was determined by DNA analysis, 17 could be advised on the basis of the $F 9$ (VIII)/TaqI RFLP result. A further three were dependent upon the $F 9$ (VIII)/X $m n I$ result and one upon the $F 9$ (XIII)/DdeI result. This sequence reflects the historical order of RFLP discovery and not all females at risk were tested for each RFLP. $F 9$ (VIII)/TaqI alone was informative for 17 of 31 $(55 \%)$ females at risk, $F 9$ (VIII)/ $X m n I$ alone was informative for four of $15(27 \%)$ females at risk

I

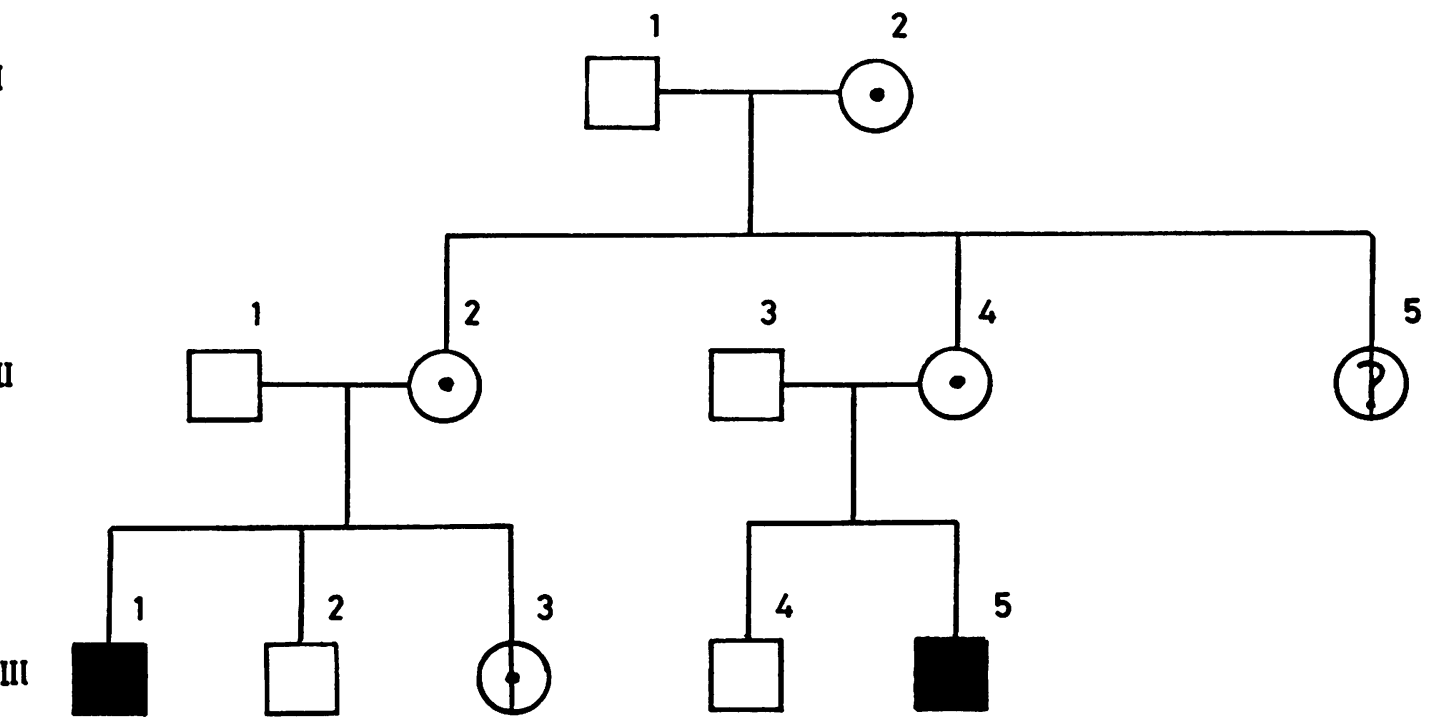

【I

FIG 7 Pedigree 4551. 
II

III

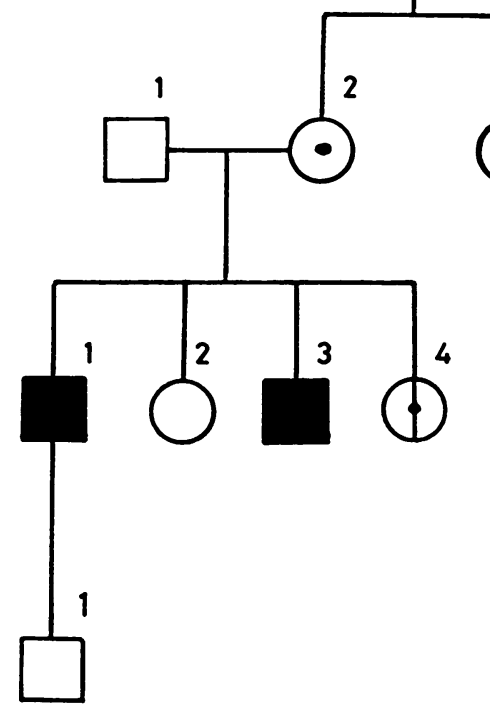

FIG 8 Pedigree 4555.

tested, and $F 9(\mathrm{XIII}) / D d e \mathrm{I}$ alone was informative for five of $15(33 \%)$ females at risk tested. The DNA results on carriers detected in the course of this study are indicated in table 3 . All nine could be offered prenatal diagnosis by DNA analysis and four were informative for all three intragenic RFLPs. Overall, prenatal diagnosis by DNA analysis could be offered to 31 of $37(84 \%)$ carriers (obligate and detected) in these families.

In these families, seven females at risk cannot be counselled despite DNA analysis and coagulation studies. For two of these females the problem is maternal non-information for all three intragenic RFLPs (pedigree 4542, IV.13; pedigree 4551, II.5) and for the other five unavailability of one or both parents for testing prevented interpretation of the consultand's DNA result (pedigree 1756, III.7; pedigree 3569, II.4 and III.6; pedigree 4542, III.2 and

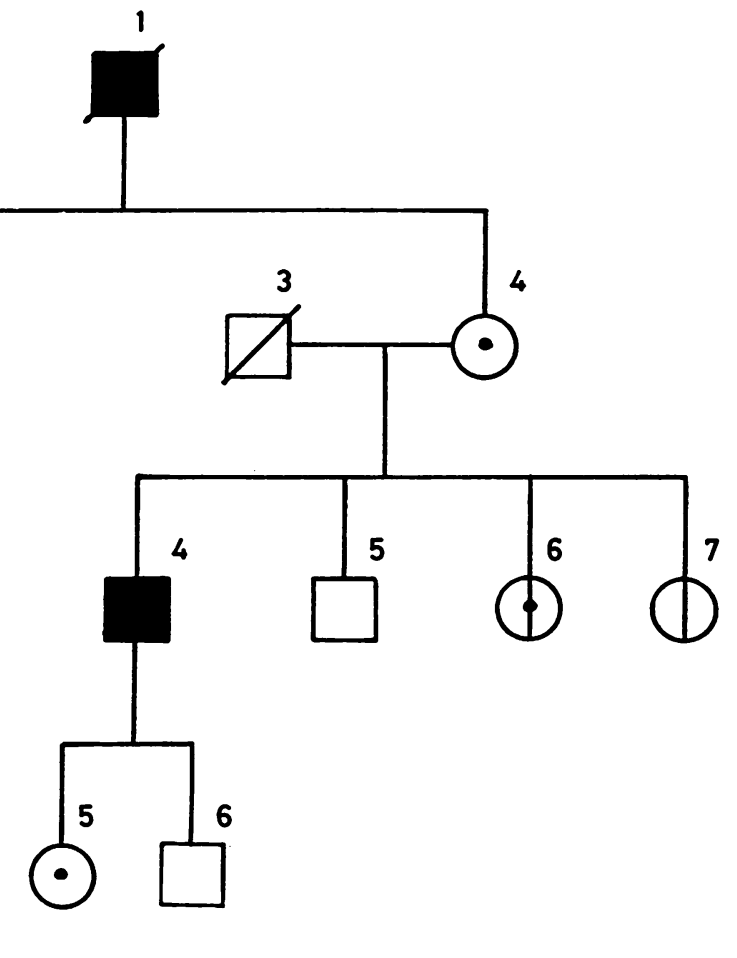

I

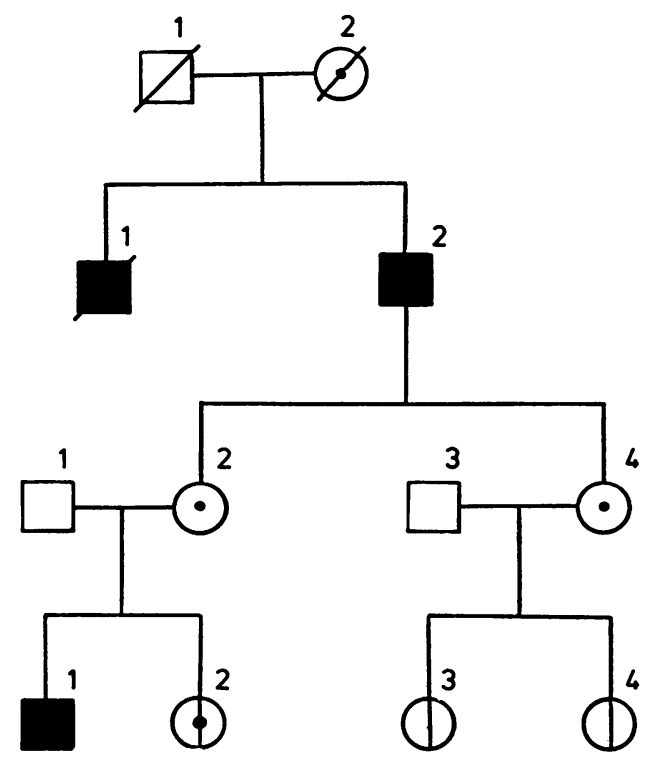

HG 9 Pedigree 4559. 


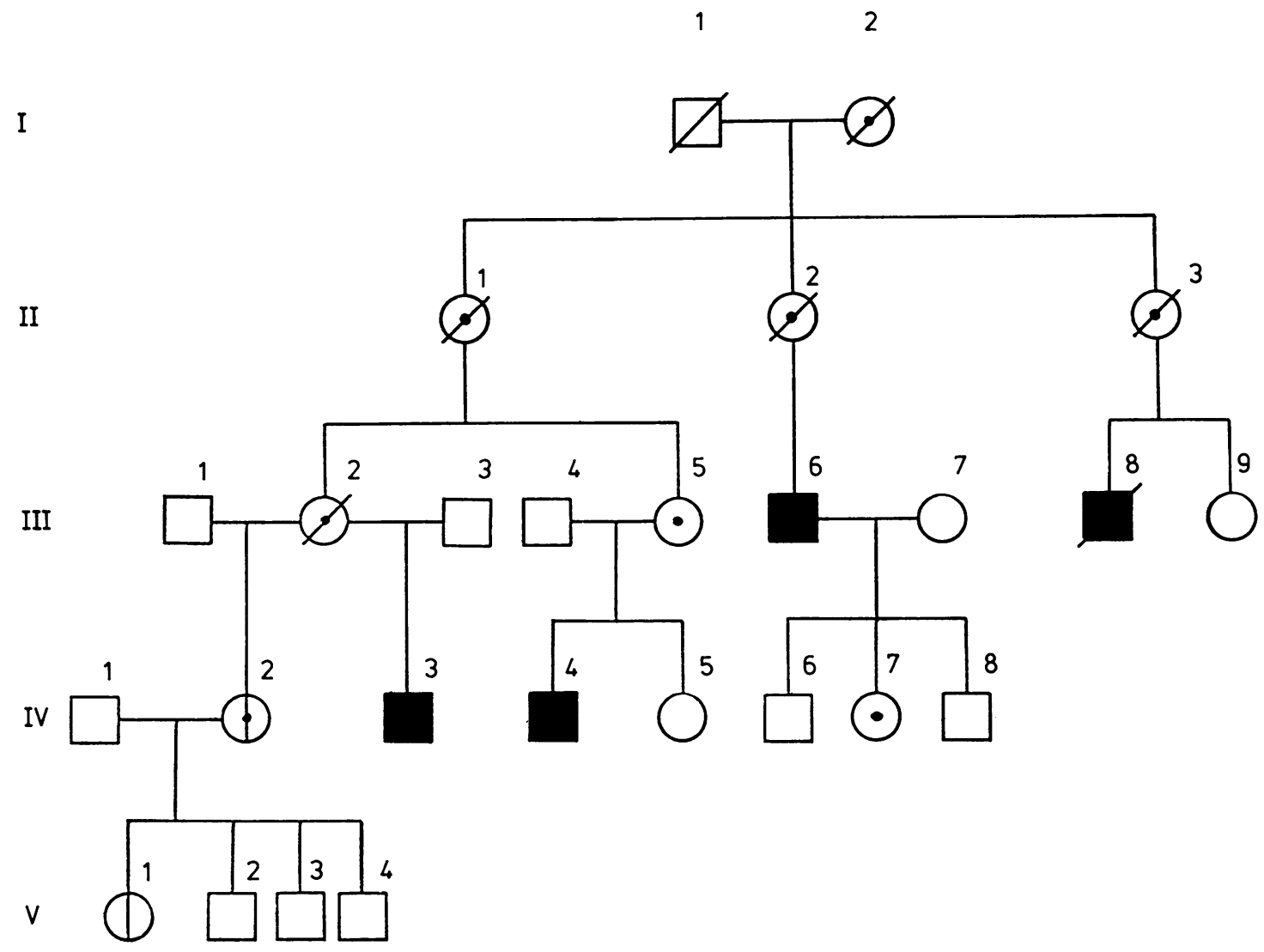

FIG 10 Pedigree 4565.

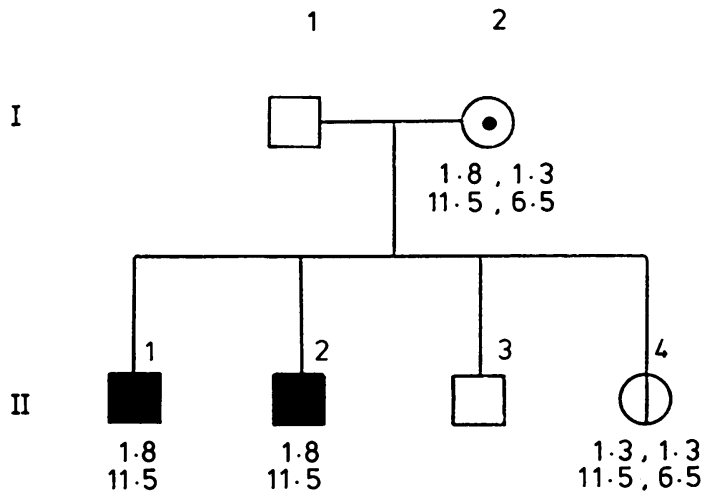

FIG 11 Partial pedigree (5215) of a family with haemophilia $B$. In this family the average level of factor IX activity is $1 \%$ in the affected males. The RFLP results for F9(VIII)/TaqI and $F 9(V I I I) / X m n I$ are indicated for each subject.
III.3). Three of this later group are, however, beyond reproductive age.

The usefulness of each RFLP is less than predicted due to linkage disequilibrium between these three polymorphisms within the factor IX gene. Table 4 compares the observed intragenic RFLP haplotypes in 31 normal $X$ chromosomes with the numbers expected assuming random association on the basis of population fragment frequencies. Thus, two-thirds of normal factor IX genes studied had 1.3-11.5-1.7, $1 \cdot 3-11 \cdot 5-1 \cdot 75$, or $1 \cdot 8-11 \cdot 5-1 \cdot 7$ haplotypes. A goodness of fit analysis shows that the difference from observed frequency is statistically significant $(\mathrm{p}<$ 0.05 ). Three different haplotypes are apparent in the haemophilia B families, two of which are common among the normal population.

\section{Discussion}

Winship et $a l^{2}$ characterised the two new factor IX intragenic polymorphisms. The $F 9$ (VIII)/XmnI 
TABLE 2 DNA analysis on obligate carriers for haemophilia $B$ (fragment sizes are in kb and fragment heterozygotes are underlined).

\begin{tabular}{|c|c|c|c|c|}
\hline \multirow{2}{*}{$\begin{array}{l}\text { Pedigree } \\
\text { No }\end{array}$} & \multirow[t]{2}{*}{ Subject } & \multicolumn{3}{|l|}{$R F L P$} \\
\hline & & $F 9(И I I) / T a q I$ & $F 9(И I I) / X m n I$ & $F 9(X I I I) / D$ deI \\
\hline \multirow[t]{2}{*}{1756} & III.8 & $1 \cdot 8,1 \cdot 3$ & $11 \cdot 5,11 \cdot 5$ & $1 \cdot 75.1 \cdot 7$ \\
\hline & III.9 & $1 \cdot 8.1 \cdot 3$ & $11 \cdot 5,11 \cdot 5$ & $1 \cdot 75.1 \cdot 7$ \\
\hline \multirow[t]{6}{*}{2377} & II. 2 & $1 \cdot 8.1 \cdot 3$ & $11 \cdot 5,11 \cdot 5$ & $1.7,1.7$ \\
\hline & III.2 & $1 \cdot 8.1 \cdot 3$ & $11 \cdot 5.6 .5$ & $1.7,1.7$ \\
\hline & 11.9 & $1 \cdot 8.1 \cdot 3$ & 11.5 .6 .5 & $1.75 .1 \cdot 7$ \\
\hline & III.8 & $1 \cdot 3,1 \cdot 3$ & $11 \cdot 5,11 \cdot 5$ & 1.7 .1 .7 \\
\hline & III.13 & $1 \cdot 3,1 \cdot 3$ & $11 \cdot 5,11 \cdot 5$ & $1.7 \quad 1.7$ \\
\hline & IN.5 & $1 \cdot 3,1 \cdot 3$ & $11 \cdot 5,11 \cdot 5$ & $1 \cdot 75.1 \cdot 7$ \\
\hline \multirow{2}{*}{3569} & II. 2 & $1 \cdot 3,1 \cdot 3$ & $11 \cdot 5,6 \cdot 5$ & $1.7,1.7$ \\
\hline & III. 2 & $1 \cdot 8,1 \cdot 3$ & $11 \cdot 5,11 \cdot 5$ & $1 \cdot 75.1 \cdot 7$ \\
\hline \multirow{4}{*}{4542} & III.1 & $1 \cdot 3,1 \cdot 3$ & $11 \cdot 5,11 \cdot 5$ & $1.75 .1 \cdot 7$ \\
\hline & III.7 & $1 \cdot 3,1 \cdot 3$ & $11 \cdot 5,11 \cdot 5$ & $1 \cdot 7,1 \cdot 7$ \\
\hline & IV.10 & $1 \cdot 3,1 \cdot 3$ & $11 \cdot 5,11 \cdot 5$ & $1 \cdot 75,1 \cdot 7$ \\
\hline & v.3 & $1 \cdot 3,1 \cdot 3$ & $11 \cdot 5,11 \cdot 5$ & $1 \cdot 7-, 1 \cdot 7$ \\
\hline \multirow{5}{*}{4549} & 1.2 & $1 \cdot 3,1 \cdot 3$ & $11.5,6.5$ & $1 \cdot 75.1 \cdot 7$ \\
\hline & 11.4 & $1 \cdot 3,1 \cdot 3$ & $\overline{11.5 .6 .5}$ & $1.75,1 \cdot 7$ \\
\hline & Il.6 & $1 \cdot 3,1 \cdot 3$ & $6 \cdot 5,6 \cdot 5$ & $1 \cdot 75.1 \cdot 7$ \\
\hline & III.I & $1 \cdot 8,1 \cdot 3$ & $11 \cdot 5,6.5$ & 1.7 .1 .7 \\
\hline & III.2 & $1 \cdot 3,1 \cdot 3$ & NT & NT \\
\hline \multirow[t]{3}{*}{4551} & 1.2 & $1 \cdot 8,1 \cdot 8$ & $11 \cdot 5,11 \cdot 5$ & $1 \cdot 7,1 \cdot 7$ \\
\hline & II. 2 & $1 \cdot 8.1 \cdot 3$ & $11 \cdot 5,11 \cdot 5$ & $1 \cdot 7.1 \cdot 7$ \\
\hline & II.4 & $1 \cdot 8.1 \cdot 3$ & $11 \cdot 5,11 \cdot 5$ & $1 \cdot 7,1 \cdot 7$ \\
\hline \multirow[t]{2}{*}{4555} & II.4 & $1 \cdot 3,1 \cdot 3$ & $11 \cdot 5.6 .5$ & $1 \cdot 75.1 \cdot 7$ \\
\hline & IN.5 & $1 \cdot 3,1 \cdot 3$ & $11 \cdot 5,11 \cdot 5$ & 1.75 .1 .7 \\
\hline \multirow[t]{2}{*}{4559} & III.2 & $1 \cdot 8.1 \cdot 3$ & $11 \cdot 5,11 \cdot 5$ & 175.17 \\
\hline & III.4 & $1 \cdot 8,1 \cdot 3$ & $11 \cdot 5,11 \cdot 5$ & $1 \cdot 7,1 \cdot 7$ \\
\hline 4565 & IV.7 & $1 \cdot 8.1 \cdot 3$ & $11 \cdot 5,11 \cdot 5$ & $1 \cdot 7,1 \cdot 7$ \\
\hline 5215 & 1.2 & $1 \cdot 8.1 \cdot 3$ & $11.5,6.5$ & 1.7 .1 .7 \\
\hline \multirow{5}{*}{$\begin{array}{l}\text { Totals } \\
\text { for } \\
\text { obligate } \\
\text { carriers }\end{array}$} & & $1 \cdot 8,1 \cdot 8$ & $11 \cdot 5,11 \cdot 5$ & $1 \cdot 75,1 \cdot 75$ \\
\hline & & $1 / 28$ & $18 / 27$ & $0 / 27$ \\
\hline & & $\frac{1 \cdot 8.1 \cdot 3}{13 / 28}$ & $\frac{11.5 .6 .5}{8 / 27}$ & $\frac{1 \cdot 75.1 \cdot 7}{12 / 27}$ \\
\hline & & $1 \cdot 3,1 \cdot 3$ & $6 \cdot 5,6 \cdot 5$ & $1 \cdot 7,1 \cdot 7$ \\
\hline & & $14 / 28$ & $1 / 27$ & $15 / 27$ \\
\hline
\end{tabular}

NT = not tested.

The intragenic factor IX haplotypes associated with the disease mutation in each family are: pedigree $1756,1 \cdot 3 / 11 \cdot 5 / 1 \cdot 7 ; 2377,1 \cdot 3 / 11 \cdot 5 / 1 \cdot 7 ; 3569,1 \cdot 3 / 11 \cdot 5 / 1 \cdot 7 ; 4542$, $1 \cdot 3 / 11 \cdot 5 / 1 \cdot 7 ; 4549,1 \cdot 3 / 6 \cdot 5 / 1 \cdot 7 ; 4551,1 \cdot 8 / 11 \cdot 5 / 1 \cdot 7 ; 4555,1 \cdot 3 / 11 \cdot 5 / 1 \cdot 7 ; 4559,1 \cdot 8 / 11 \cdot 5 / 1 \cdot 7 ; 4565,1 \cdot 8 / 11 \cdot 5 / 1 \cdot 7 ;$ and $5215,1 \cdot 8 / 11 \cdot 5 / 1 \cdot 7$. The $\mathrm{RFLP}$ order is as in the table.

RFLP is a site polymorphism which lies 4 to $4.5 \mathrm{~kb}$ $5^{\prime}$ to the $F$ 9(VIII)/TaqI site polymorphism. The $F 9$ (XIII)/DdeI RFLP is $1.5 \mathrm{~kb}^{\prime} 5^{\prime}$ to the F9(VIII)/ $X m n I$ RFLP and is a length polymorphism due to a $50 \mathrm{bp}$ insertion of $Z$ type DNA sequence. Thus, these three RFLPs are within $6 \mathrm{~kb}$ of each other within the factor IX gene. Edwards ${ }^{8}$ has estimated that a DNA segment $100 \mathrm{~kb}$ long has only a $50 \%$ chance of rearrangement in 700 generations or about 20000 years. Hence, any haemophilia B family, even if extensive, would be expected to show non-random association (linkage disequilibrium) with a particular intragenic RFLP haplotype. Similarly, linkage disequilibrium would be expected between each of the RFLPs. This was apparent in the present study and also in that of Winship et al, ${ }^{2}$ although only pairs of RFLPs were presented in the latter study.

If a disease mutation is very rare and is selectively neutral or advantageous (to the heterozygote), then linkage disequilibrium may be apparent at a population level. This has been observed for haemoglobin $S,{ }^{9}$ several $\beta$ thalassaemia mutations, ${ }^{10}$ and the $Z$ allele of $\alpha_{1}$ antitrypsin deficiency. ${ }^{1}$ i It was not apparent in the present study and this would suggest that most of the haemophilia B mutations are of relatively recent origin, as might be expected for a deleterious $\mathrm{X}$ linked trait.

Linkage disequilibrium has an important practical consequence. In the present study, although each newly discovered RFLP increased the proportion of females at risk who could be definitively counselled, the yield with each new RFLP was successively less. Despite this limitation, the combination of three intragenic RFLPs permitted definitive carrier detection in $68 \%$ of females at risk. This is a significant improvement in comparison with the use of only a 
TABLE 3 DNA analysis on carriers detected by DNA analysis or haematological testing (fragment sizes are in kb and fragment heterozygotes are underlined).

\begin{tabular}{|c|c|c|c|c|}
\hline \multirow{2}{*}{$\begin{array}{l}\text { Pedigree } \\
\text { No }\end{array}$} & \multirow[t]{2}{*}{ Subject } & \multicolumn{3}{|l|}{$R F L P$} \\
\hline & & $F 9(И I I) / T a q I$ & $F 9(И I I) / X m n I$ & $F 9(X I I I) / D$ deI \\
\hline 1756 & IV.10 & $1 \cdot 3,1 \cdot 3$ & $11 \cdot 5,11 \cdot 5$ & $1 \cdot 75.1 \cdot 7$ \\
\hline 2377 & IV.2 & $1 \cdot 8,1 \cdot 3$ & $11 \cdot 5,11 \cdot 5$ & $1 \cdot 75.1 \cdot 7$ \\
\hline 3569 & IV.2 & $1 \cdot 3,1 \cdot 3$ & $11 \cdot 5,11 \cdot 5$ & $1 \cdot 75,1 \cdot 7$ \\
\hline 4549 & III.5 & $1 \cdot 8.1 \cdot 3$ & $11 \cdot 5,6.5$ & $1 \cdot 75,1 \cdot 7$ \\
\hline 4551 & III. 3 & $1.8 .1 \cdot 3$ & $11.5,6.5$ & $1 \cdot 75,1 \cdot 7$ \\
\hline 4555 & IV.4 & $1 \cdot 8.1 \cdot 3$ & $11 \cdot 5.6 .5$ & $1 \cdot 75.1 \cdot 7$ \\
\hline 4559 & 11.2 & $1 \cdot 8.1 \cdot 3$ & $11 \cdot 5,6.5$ & $1 \cdot 75,1 \cdot 7$ \\
\hline 4565 & IV.2 & $1 \cdot 8.1 \cdot 3$ & $11 \cdot 5,6 \cdot 5$ & $1.7,1.7$ \\
\hline
\end{tabular}

TABLE 4 Intragenic factor IX haplotypes in 31 normal $X$ chromosomes.

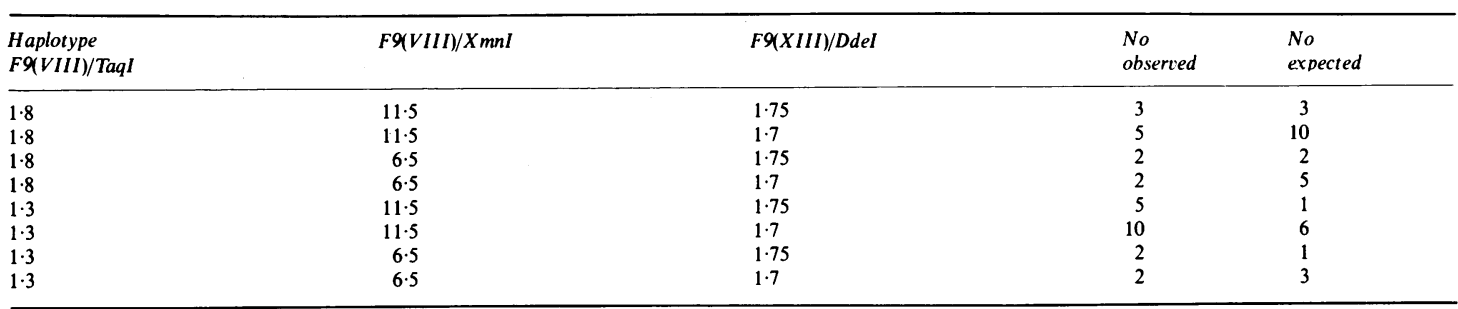

single intragenic RFLP, which in turn is better than haematological testing alone for carrier detection in haemophilia B. The delineation of further intragenic or flanking tightly linked RFLPs should improve carrier detection by DNA analysis still further, but for most (five of seven) of our females at risk, who cannot yet be counselled using this technology, the problem is non-availability of parental DNA. This renders DNA interpretation impossible except by the demonstration of homozygosity for the non-disease linked RFLP fragment. In this situation, direct detection of a mutation within a family, perhaps via an oligonucleotide probe, might be of clinical value.

The clinical and haematological variation among families with haemophilia B no doubt reflects a diverse heterogeneity of molecular pathology. Complete factor IX gene deletions appear to be rare but have been a consistent finding in patients who develop antifactor IX antibodies. ${ }^{12-14}$ Chen et al $^{15}$ have described a family with a partial factor IX deletion of $10 \pm 0.3 \mathrm{~kb}$ which included the two exons coding for amino acids 85 to 195 . Despite this large deletion, there was evidence of transcription and translation of the gene and no antifactor IX antibodies were produced. A point mutation is suspected for factor IX Chapel Hill on the basis of an altered amino acid composition with substitution of histidine for arginine at position $145 .{ }^{16}$ More recently, a donor splice site mutation at the $3^{\prime}$ end of exon $f$ with GT replaced by TT has been demonstrated in a patient with severe CRM negative haemophilia $\mathrm{B}$, and oligonucleotide probes were constructed which could be used for carrier detection in this family. ${ }^{17}$ However, this involved sequence analysis of the entire factor IX gene in order to define the disease mutation and screening of 14 further severe CRM negative patients with haemophilia $B$ using this allele specific oligonucleotide probe did not detect further examples of this mutation. Thus, for practical purposes, carrier detection by intragenic RFLPs is likely to remain the first line of approach for carrier detection in haemophilia B.

We wish to thank Professor G G Brownlee of the University of Oxford who generously gave us the factor IX probes. We also wish to thank the Wellcome Trust and the National Fund for Research into Crippling Diseases for financial support.

\section{References}

1 Gianelli F, Anson DS, Choo KH, et al. Characterisation and use of an intragenic polymorphic marker for the detection of carriers of haemophilia B (factor IX deficiency). Lancet $1984 ; \mathbf{i} ; 239-41$. 
2 Winship PR, Anson DS, Rizza CR, Brownlee GG. Carrier detection in haemophilia $B$ using 2 further intragenic restriction fragment length polymorphisms. Nucleic Acids Res 1984; 12:8861-72.

3 Gruenebraum L, Casenave JP, Camerino G, et al. Carrier detection of haemophilia B by using a restriction site polymorphism associated with the coagulation factor IX gene. $J$ Clin Invest 1984;73:1491-5.

4 Connor JM, Pettigrew AF, Hann IM, Forbes CD, Lowe GDO, Affara NA. Application of an intragenic genomic probe to genetic counselling for haemophilia B in the west of Scotland. $J$ Med Genet 1985;22:441-6.

5 Harper K, Winter R, Pembrey M, et al. A clinically useful DNA probe closely linked to haemophilia A. Lancet 1984;ii:6-8.

6 Gitschier J, Lawn RM, Rotblat F, Goldman E, Tuddenham EGD. Antenatal diagnosis and carrier detection of haemophilia A using factor VIII gene probe. Lancet 1985;i:1093-4.

7 Gianelli F, Choo KH, Rees DJG, Boyd Y, Rizza CR, Brownlee GG. Gene deletions in patients with haemophilia B and antifactor IX antibodies. Nature 1983;303:181-2.

8 Edwards JH. Population genetics of $\mathrm{C} 4$ with the use of complementary DNA probes. Philos Trans $R$ Soc Lond $[B i o l]$ 1984;306:405-17.

9 Kan Y, Dozy AM. Polymorphisms of DNA sequence adjacent to human $\beta$-globin structural gene: relation to sickle mutation. Proc Natl Acad Sci USA 1978;75:5631-5.

10 Orkin SH, Kazazian H, Antonarakis SE, et al. Linkage of $\beta$-thalassaemia mutations and $\beta$-globin gene polymorphisms with DNA polymorphisms in human $\beta$-globin gene cluster. Nature 1982;296:627-31.

11 Cox DW, Woo SLC, Mansfield T. DNA restriction fragments associated with $\alpha$-antitrypsin indicate a single origin for deficiency allele PI Z. Nature 1985;316:79-81.

12 Gianelli F, Choo K, Rees DJG, et al. Gene deletions in patients with haemophilia B and anti-factor IX antibodies. Nature 1983;303:181-2.

13 Peake IR, Furlong BL, Bloom AL. Carrier detection by direct gene analysis in a family with haemophilia B (factor IX deficiency). Lancet 1984;i:242-3.

14 Bernardi F, Del Senno L, Barbieri R, et al. Gene deletion in an Italian haemophilia B subject. J Med Genet 1985;22:305-7.

15 Chen SS, Kurachi K, Yoshitake S. et al. Point mutation and intragenic deletion of factor IX gene as a cause of hemophilia B. Am J Hum Genet 1985;37(suppl):A7.

16 Noyes CM, Griffith MJ, Roberts R, Lundblad RL. Identification of the molecular defect in factor IX Chapel Hill: substitution of histidine for arginine at position 145. Proc Natl Acad Sci USA 1983;80:4200-2.

17 Rees DJG, Rizza CR, Brownlee GG. Haemophilia B caused by a point mutation in a donor splice junction of the human factor IX gene. Nature 1985;316:643-5.

Correspondence and requests for reprints to $\mathrm{Dr}$ J M Connor, Duncan Guthrie Institute of Medical Genetics, Yorkhill, Glasgow G3 8SJ. 